\title{
HIV og alnæmi 30 árum síðar
}

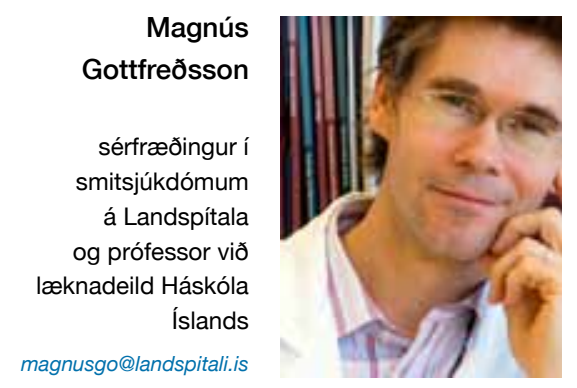

Sumarið 1981 birtust tvær stuttar greinar sem létu lítið yfir sér par sem lýst var nokkrum tilfellum af sérkennilegri sýkingu, Pneumocystis carinii (nú P. jiroveci) lungnabólgu hjá ungum karlmönnum í Kaliforníu og New York. ${ }^{1,2}$ Aðeins einu ári síðar hafði ápekkum tilfellum fjölgað gríðarlega. Menn gerðu sér grein fyrir að vandamálið væri nýtt, víðtæk ónæmisbilun sem fékk sjúkdómsheitið AIDS, eða alnæmi á íslensku. Árið 1983 var HIV fyrst lýst og í kjölfarið varð ljóst að um heimsfaraldur var að ræða. Útbreiðslan var hröð pótt sjúkdómseinkenni kæmu seint fram. Fyrstu ár alnæmisfaraldursins einkenndust af tilfinningaprunginni umræðu, óvissu og úrræðaleysi. Sjúkdómurinn var illviðráđanlegur og dró fólk til dauða fyrir aldur fram. Nú er talið að rúmlega 33 milljónir jarðarbúa séu HIVsmitaðir og að tvær milljónir deyi árlega af völdum veirunnar. Prátt fyrir pessar nöturlegu staðreyndir hafa framfarir í lyfjameðferð gegn HIV verið gríðarlegar undanfarin 15 ár. Samsett meðferð með and-retroveirulyfjum hefur stórbætt horfur peirra sem greinast. Nýir lyfjaflokkar hafa komið fram á sjónarsviðið. Mörg hinna nýju lyfja beinast að skotmörkum í HIV sem áður voru utan seilingar, svo sem integrasa og kemokín-viðtökum. Pessu til viðbótar hafa nú í fyrsta sinn birst jákvæðar vísbendingar um bóluefni. Á forsíðu hins vinsæla tímarits The Economist í sumar var velt vöngum yfir mögulegum endalokum alnæmisfaraldursins, eða „The end of
AIDS?" sem er lýsandi fyrir pá bjartsýni sem nú ríkir.

Smitleiðir HIV eru flestum kunnar, en pær eru óvarin kynmök, smit frá móður til barns og snerting við sýkta vefi eins og við blóðgjöf eða hjá sprautufíklum sem deila nálum. Vægi smitleiðanna er pó mismunandi eftir löndum og tímabilum. Hlutdeild innflytjenda meðal nýgreindra HIV-smitaðra á Norðurlöndunum hefur aukist undanfarinn áratug. Einnig eru sterkar vísbendingar um að HIV sé í sókn meðal samkynhneigðra karlmanna í nágrannalöndum okkar. Á hinn bóginn hefur nýgengi meðal sprautufíkla verið á niðurleið í Evrópu, en sprautufíklar eru par $<5 \%$ nýrra tilfella að jafnaði. Meðaltalstölur segja pó ekki alla söguna. Útbreiðsla HIV er hröð pegar veiran berst í hóp fíkniefnaneytenda. Nágrannar okkar, bæði Svíar og Finnar, hafa bitra reynslu af slíkum faröldrum, en bitrust er pó reynsla Eista, par sem 60-90\% allra sprautufíkla smituðust af HIV á skömmum tíma. En hver er staðan á Íslandi? Til skamms tíma var HIV ekki vandamál meðal sprautufíkla hér, en pað hefur breyst hratt undanfarna mánuði. Árið 2010 bættust 24 einstaklingar í hóp HIV-smitaðra hérlendis, fleiri en nokkru sinni. Margt bendir til að pað met verði jafnað eða jafnvel slegið árið 2011. Flestir hinna nýgreindu einstaklinga eru sprautufíklar sem sprauta sig með örvandi efnum í æð, svo sem amfetamíni eða metýlfenídati (ritalíni). Á göngudeild smitsjúkdóma á Landspítala er hlutfall sprautufíkla meðal HIV-smitaðra pegar komið yfir 20\%, sem er hærra hlutfall en bæði í Stokkhólmi og Helsinki. Peir sem misnota metýlfenídat eru oft stjórnlausir í sinni neyslu og hvatvísir, sem veldur pví að peir sprauta sig mun oftar en aðrir fíklar. Peir eru síður líklegir til að nota hreinar nálar pví að vímuástand peirra brenglar áhættumat. Reynsla Finna bendir og til pess að meirihluti sprautufíkla stundi óvarið kynlíf prátt fyrir HIV-smit, og auki pannig útbreiðsluna enn frekar. Hvert nýtt tilfelli er afar kostnaðarsamt fyrir heilbrigðiskerfið, um 1 milljón evra, eða nálægt 160 milljónum króna. Pví er mikilvægt að hefta útbreiðsluna með öllum tiltækum ráðum. Hvað felst í pví? 1) Bæta parf aðgengi fíkla að ókeypis sprautum og nálum. Hér hefur aðgengi verið allgott, en betur má ef duga skal. Reynsla annarra pjóða sem glímt hafa við svipaðan vanda mælir eindregið með pví. 2) Bæta parf aðgengi sprautufíkla að félags- og heilbrigðispjónustu og veita pjónustuna í nærumhverfi peirra. 3) Auka parf fræðslu um gagnsemi smokka og gera pá aðgengilegri. Smokkar ættu að vera fáanlegir án endurgjalds á skemmtistöðum, í framhaldsskólum og stöðum par sem líkur eru á að stundað sé óvarið kynlíf, svo sem í fangelsum. 4) Auka parf árvekni lækna og hvetja pá til að taka oftar HIV-próf hjá skjólstæðingum sínum. Bæði hérlendis og á hinum Norðurlöndunum gerist pað enn að sjúklingar greinast fyrst með HIV er sjúkdómurinn hefur náð lokastigi. Prófa ætti alla fíkla, pá sem lifa óvörðu kynlífi og eru í fangelsum. 5) Draga úr smithættu með lyfjameðferð. Lyfjameðferð gegn HIV hefur stórbatnað og pað má velta pví fyrir sér hvort ávinningur væri af pví að hefja meðhöndlun pótt hefðbundnum meðferðarskilmerkjum hafi ekki verið náð. 6) Sporna gegn ofnotkun og misnotkun örvandi lyfja, aðallega metýlfenídats.

Vandamálið mun ekki hverfa, en við getum dregið úr umfangi pess. Slík viðbrögð eru besta fjárfestingin til framtíðar.

1. Centers for Disease Control (CDC). Pneumocystis pneumonia - Los Angeles. MMWR Morb Mortal Wkly Rep 1981; 30: 250-2.

2. Centers for Disease Control (CDC). Kaposi's sarcoma and Pneumocystis pneumonia among homosexual men - New York City and California. MMWR Morb Mortal Wkly Rep 1981; 30: 305-8.

HIV and AIDS 30 years later

Magnús Gottfredsson, MD, PhD, FACP, Consultant in Infectious Diseases, Professor of Medicine, University of Iceland, Faculty of Medicine 